\title{
Genetics of Eucalyptus wood properties
}

\author{
Carolyn A. Raymond* \\ CSIRO Forestry and Forest Products and Cooperative Research Centre for Sustainable Production Forestry, GPO Box 252-12, Hobart, TAS 7001, Australia
}

(Received 5 July 2001; accepted 5 March 2002)

\begin{abstract}
Traditional methods of assessing wood properties are both destructive and expensive, limiting the numbers of samples that can be processed. Over the past decade, non-destructive sampling techniques and new assessment methods have been developed leading to a large increase in the numbers of trees and traits that can be evaluated. This technology has enabled the assessment of progeny trials to determine the patterns of variation, degree of genetic control and economic importance of many wood traits, leading to the inclusion of wood properties in many eucalypt-breeding programs. Issues addressed in this paper include the potential markets and products for plantation eucalypts leading to a definition of which wood properties should be assessed for a range of products. Current recommendations for non-destructive sampling for basic density, fibre length and predicted pulp yield in Eucalyptus globulus and E. nitens are provided. Other non-destructive assessment techniques are illustrated including cellulose content, acoustic testing methods for wood stiffness and SilviScan X-ray densitometry and diffraction analysis for density and microfibril angle. The degree of genetic control for wood properties is compared to tree growth traits and a series of issues and challenges for the future presented.
\end{abstract}

eucalypt / breeding / wood quality / genetic parameters / non-destructive sampling

Résumé - Génétique des propriétés du bois d'Eucalyptus. Les méthodes traditionnelles pour déterminer les propriétés du bois sont à la fois destructives et chères, limitant le nombre d'échantillons pouvant être étudiés. Au cours des décennies passées, les techniques d'échantillonnage non destructives et les méthodes nouvelles d'évaluation ont été développées. Elles conduisent à une forte augmentation dans le nombre d'arbres et de caractères pouvant être évalués. Cette technologie a permis l'évaluation d'expériences progéniques afin de déterminer les formes de variation, le degré de contrôle génétique et l'importance économique de nombreuses caractéristiques du bois. Cela a conduit à l'incorporation de l'étude des propriétés du bois dans de nombreux programmes d'amélioration de l'eucalyptus. Les messages adressés dans ce papier incluent les marchés et produits potentiels pour les plantations d'eucalyptus conduisant à une définition pour laquelle les propriétés du bois devront être prises en compte pour une série de produits. Les recommandations actuelles sont données pour le cas d'un échantillonnage non destructif pour la mesure de la densité basique du bois, de la longueur de fibre et la production prévisible de pâte pour Eucalyptus globulus et E. nitens. D'autres évaluations techniques non destructives sont illustrées. Elles incluent la teneur en cellulose, des méthodes de test acoustique pour la dureté du bois et des analyses densitométriques et de diffraction par l'analyseur rayons X, SilviScan, pour la densité et l'angle des microfibres. Le niveau de contrôle génétique pour les propriétés du bois est comparé aux caractéristiques de la croissance des arbres et une série d'attendus et de challenges pour le futur est présentée.

eucalyptus / croisement / qualité du bois / paramètres génétiques / échantillonnage non destructif

\section{INTRODUCTION}

Breeding of eucalypts for traits of commercial importance is a relatively recent development and linked to the increase in the establishment of plantations. After initial studies to determine the suitability of species and provenances for particular environments, progeny trials were established, often on a range of sites, allowing the estimation of genetic parameters and genotype by environment interactions. The early studies on genetics of eucalypts concentrated on tree growth, survival, stem straightness and branch quality. As breeding programs progressed the range of traits assessed increased to include fitness, which relate to the ability of trees to survive environmental threats, and to quality, of which those pertaining to wood quality are amongst the most important [7].

* Correspondence and reprints

Tel.: 613 62267948; fax: 613 62267901; e-mail: carolyn.raymond@ csiro.au 
Limited work on assessing wood quality traits in breeding programs had been undertaken prior to the 1990's for several reasons. Within tree breeding programs there is a requirement to assess large numbers of individual trees and families for traits of economic importance. However, traditional methods of assessment for wood quality traits are expensive and restrict the numbers of samples that can be processed. In addition, traditional assessment methods involve the destruction of the sampled trees. For species that do not reliably propagate vegetatively, such as E. globulus and E. nitens, destructive sampling will result in the loss of valuable genotypes for breeding.

Priority areas for research in wood quality over the past decade have been: (a) developing breeding objectives for different products; (b) developing non-destructive sampling methods; (c) evaluating alternative traits or methods for use as indicators for traits that are more expensive to assess; and (d) assessing the degree and structure of genetic variation for each wood quality trait. Each of these areas is important when developing breeding strategies and are addressed in this paper, with emphasis on the key temperate plantation species: Eucalyptus globulus and Eucalyptus nitens.

\section{BREEDING OBJECTIVES, MARKETS AND PRODUCTS}

Currently, the major market for eucalypt wood is the pulp and paper industry with the major product classes being newsprint from cold soda pulping or fine writing and photocopy paper from kraft pulping. In recent years, there has been increasing interest in using plantation eucalypts for producing sawn timber, veneers and reconstituted wood products. For each production system it is essential to define what it is that you wish to breed for.

Breeding objectives have been developed for unbleached kraft pulp [7] and for newsprint [17] but not for solid or reconstituted wood products. Breeding objectives should be based on a clear definition of the key economic parameters driving the production system. Table I presents a summary of
Table II. Key wood properties for a range of product classes.

\begin{tabular}{lll}
\hline Pulp and paper & Sawn timber & Composites \\
\hline Basic density & Basic density and gradient & Basic density \\
Pulp yield / cellulose & Microfibril angle & Lignin content \\
content & Strength and stiffness & Extractives content \\
Fibre length & Dimensional stability & Cellulose content \\
& Shrinkage and collapse & \\
& Tension wood & \\
& Knot size & \\
& Incidence of decay, spiral grain & \\
& and end splits & \\
\hline
\end{tabular}

the economic drivers for a range of markets and products [7, $15,17]$.

Once the economic parameters are defined, the next step is to determine their relationship to desirable tree, wood, processing and product characteristics so that the key wood properties may be defined for each product. Table II presents a summary of the author's current perceptions of which wood properties should be assessed for a range of products.

\section{ASSESSMENT ISSUES}

\subsection{Non-destructive sampling}

In the early 1990's a motor-driven coring system for removing $12 \mathrm{~mm}$ wood cores from standing trees was released onto the market [4]. This development made it feasible to non-destructively sample the relatively large numbers of trees required for assessing wood properties in tree breeding trials. However, little information was available, for any wood property, to indicate where the samples should be taken from to obtain a representative estimate of the whole tree wood properties.

Non-destructive sampling methods for wood properties must be developed based on knowledge of patterns of variation within the tree for the property of interest [4]. When developing an effective and efficient sampling strategy several key questions must be addressed, including: how does the wood property change up the stem and is this pattern

Table I. Markets, products and economic drivers.

\begin{tabular}{|c|c|c|c|}
\hline Market & Product class & Products & Economic drivers \\
\hline \multirow[t]{2}{*}{ Pulp and paper } & Kraft pulp & $\begin{array}{l}\text { Photocopy paper } \\
\text { Fine writing paper }\end{array}$ & Chemical consumption, pulp yield, paper quality \\
\hline & Mechanical pulp & Newsprint & Energy consumption, paper quality \\
\hline Solid timber & Sawn timber & $\begin{array}{l}\text { Furniture } \\
\text { Flooring } \\
\text { Structural }\end{array}$ & $\begin{array}{l}\text { Recovery (green and dry), grade, drying cost, drying degrade, } \\
\text { sawing productivity }\end{array}$ \\
\hline \multirow[t]{2}{*}{ Composites } & Veneers & $\begin{array}{l}\text { Furniture } \\
\text { Laminated veneer lumber }\end{array}$ & Recovery, grade, degrade during drying, glue usage \\
\hline & Composites & $\begin{array}{l}\text { Medium density fibre board } \\
\text { Oriented strand board }\end{array}$ & Resin/glue usage, energy consumption \\
\hline
\end{tabular}


consistent across sites and ages, what is the best height to remove a core, which side of the tree should be sampled, how well will the core predict the whole tree value, how many trees should be sampled and should trees be stratified based on tree size? As the sampling strategy will be applied to a large number of trees it has to be rapid and easy to use in the field and result in minimal damage to the tree.

Each of the above questions was addressed in a large study on sampling methods for basic density, fibre length, fibre coarseness and pulp yield in E. globulus and E. nitens [12, 18, 20]. Ten trees of each species were sampled from each of five sites, sectioned and optimum sampling methods determined. A summary of their sampling recommendations arising from this study is presented in table III.

\subsection{Assessment techniques}

The search for cost-effective selection criteria for assessing wood properties in breeding programs has been a major field of research over the last 10 years. Much interest centred on evaluating alternatives to kraft pulp yield, including using near infrared reflectance analysis [19-21], raman spectroscopy [14] and secondary standards, such as other chemical wood components, including hot water extractives content [16] or cellulose content [19]. In recent years there has been a large increase in interest in the assessment of solid wood properties. Current information on available assessment methods is summarised below in table $I V$.

Table III. Recommended sampling height, reliability (percentage of variation in whole tree values explained by core sample), number of trees to be sampled and accuracy of prediction of stand mean using recommended numbers of samples for basic density, fibre length, fibre coarseness and predicted pulp yield (from $[12,18,20]$ ).

\begin{tabular}{|c|c|c|c|c|}
\hline & Basic Density & Fibre Length & Fibre Coarseness & Predicted Pulp Yield \\
\hline \multicolumn{5}{|l|}{ E. globulus } \\
\hline Height (m) & 1.1 & $1.1-1.5$ & $1.1-1.5$ & $1.1-1.3$ \\
\hline Number & 8 & 13 & $13-21$ & 6 \\
\hline Accuracy & $\pm 20 \mathrm{~kg} \mathrm{~m}^{-3}$ & $\pm 5 \%$ of mean & $\pm 5 \%$ of mean & $\pm 1 \%$ \\
\hline \multicolumn{5}{|l|}{ E. nitens } \\
\hline Reliability (\%) & 89 & $68-74$ & $44-45$ & 58 \\
\hline Number & 8 & 8 & 16 & 4 \\
\hline Accuracy & $\pm 20 \mathrm{~kg} \mathrm{~m}^{-3}$ & $\pm 5 \%$ of mean & $\pm 5 \%$ of mean & $\pm 1 \%$ \\
\hline
\end{tabular}

Table IV. Methods available for assessing a range of wood properties, together with whether the method uses core samples and can be used for non-destructive testing.

\begin{tabular}{|c|c|c|c|}
\hline & Assessment method & Core sample? & Non-destructive? \\
\hline Basic density & $\begin{array}{l}\text { Gravimetric assessment } \\
\text { Pilodyn (indirect assessment) }\end{array}$ & $\mathscr{L}$ & $\mathscr{L}$ \\
\hline $\begin{array}{l}\text { Density variation } \\
\text { Density gradient }\end{array}$ & X-ray densitometry & $\mathscr{L}$ & $\mathscr{L}$ \\
\hline Microfibril angle & $\begin{array}{l}\text { X-ray diffraction } \\
\text { Confocal microscopy }\end{array}$ & & 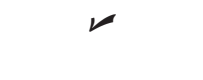 \\
\hline Pulp yield & Digestion of wood chips to given residual lignin level & & \\
\hline $\begin{array}{l}\text { Cellulose content } \\
\text { Lignin content } \\
\text { Extractives }\end{array}$ & $\begin{array}{l}\text { Chemical analysis of ground wood } \\
\text { Near infrared reflectance analysis } \\
\text { Raman spectroscopy }\end{array}$ & 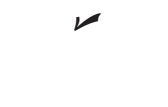 & 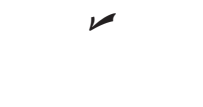 \\
\hline Fibre length & Optical measurement of separated fibres & 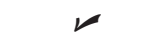 & 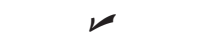 \\
\hline Growth Stresses & Displacement of markers after release of stress & & $\mathscr{L}$ \\
\hline Modulus of Elasticity & $\begin{array}{l}\text { Mechanical testing of boards or clear sections } \\
\text { Acoustic/stress wave }\end{array}$ & & \\
\hline Shrinkage & Measurement of green and dry boards & & \\
\hline Tension Wood & Histological assessment & & \\
\hline Incidence and extent of decay & $\begin{array}{l}\text { Requires tree to be felled and sectioned unless decay is sufficiently severe for cell } \\
\text { breakdown to occur. If so then timing of stress wave transmission or a Resistgraph } \\
\text { may be used for non-destructive assessment }\end{array}$ & & \\
\hline Knot size & Measurement of branch size and incidence & & $\nu$ \\
\hline
\end{tabular}


Use of a pilodyn is not recommended for indirect assessment of basic density in breeding programs due to the low heritability of pilodyn penetration. In a study on E. globulus progeny trials across three sites [11] the heritability of pilodyn ranged from 0.13 to 0.27 whilst heritabilities for density, estimated on core samples from the same trees, ranged from 0.67 to 1 . The pilodyn was also found to provide a different ranking of provenances to that provided by direct measurement of core samples. The top ranked subrace for pilodyn penetration (based on the smallest degree of penetration) at each site ranked 3rd, 4th or 5th for density.

Of the alternative methods evaluated for assessing kraft pulp yield, hot water extractives content cannot be recommended [16] due to the low correlation with pulp yield. However, cellulose content of wood, as measured using an acid diglyme digest [26], is strongly correlated with pulp yield in temperate eucalypts $[8,25]$ as shown in figure 1 .

While using this method increases the numbers of samples that may be processed, it still relies on wet chemistry, which can be time consuming and costly. A large increase in the numbers of samples processed would be possible if an indirect method, such as use of near infrared reflectance (NIR) analysis or raman spectroscopy, could be used for prediction of kraft pulp yield or cellulose content. For these methods the wood sample is ground to produce wood meal, which is then measured in a spectrophotometer. The analyses rely on developing a calibration that relates the spectra of a large number of samples to their known chemical constitution, for example pulp yield or cellulose content. This calibration is then used to predict the pulp yield or cellulose content of further samples based on their NIR spectrum. It is implicit in this technique that the "training" sets on which the calibrations are based contain the whole range of variation in the samples to be analysed. NIR analysis has recently been used to predict pulp yield [9, 22, 27] and cellulose content [19, 23, 27]. Raman spectroscopy has also been used for prediction of wood constituents, including holocellulose, $\alpha$-cellulose, lignin and extractives [14].

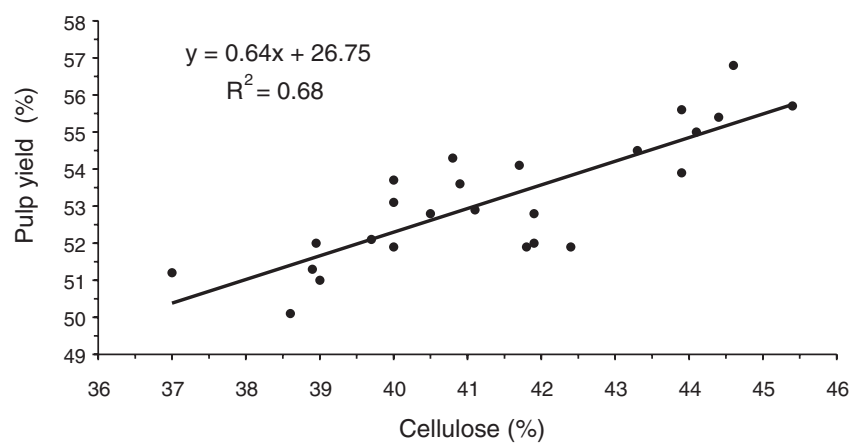

Figure 1. Relationship between cellulose content of cores at $0.9 \mathrm{~m}$ height and whole tree pulp yield at kappa 18 for 14-year-old E. nitens (from [8]).
Alternative assessment methods for solid wood products have concentrated on assessment of peripheral growth stress as an alternative to end splitting or board deflection during sawing; using acoustic methods for assessing stiffness; and alternatives for assessing drying degrade (shrinkage and collapse). For growth stresses, non-destructive sampling techniques are available $[1,13]$ but it is unclear whether these techniques, as currently applied around breast height in standing trees, are actually representative of the whole tree values for the wood property in question. Use of acoustics techniques (stress or sound wave transmission) for assessing stiffness of sawn timber is a growing area of research, which appears promising. Figure 2 presents results from a sawing study on two age classes of $E$. dunnii where sound velocity through the butt logs is compared with mean stress grade of the dried boards.

Assessment of density variation, density gradient and microfibril angle are now possible using X-ray densitometry and analysis of diffraction patterns. For example, SilviScan-2 [4] generates radial profiles of air-dry density and microfibril angle (figure 3).

\subsection{Age at assessment}

The age at which each wood property may be reliably assessed, with respect to predicting values at harvest, is important. The earlier the wood property is assessed, the more rapidly selections can be used for breeding and the greater the rate of genetic gain per unit time. Decisions about when and how to assess different wood properties must be based on the patterns of change over time and the accuracy of the

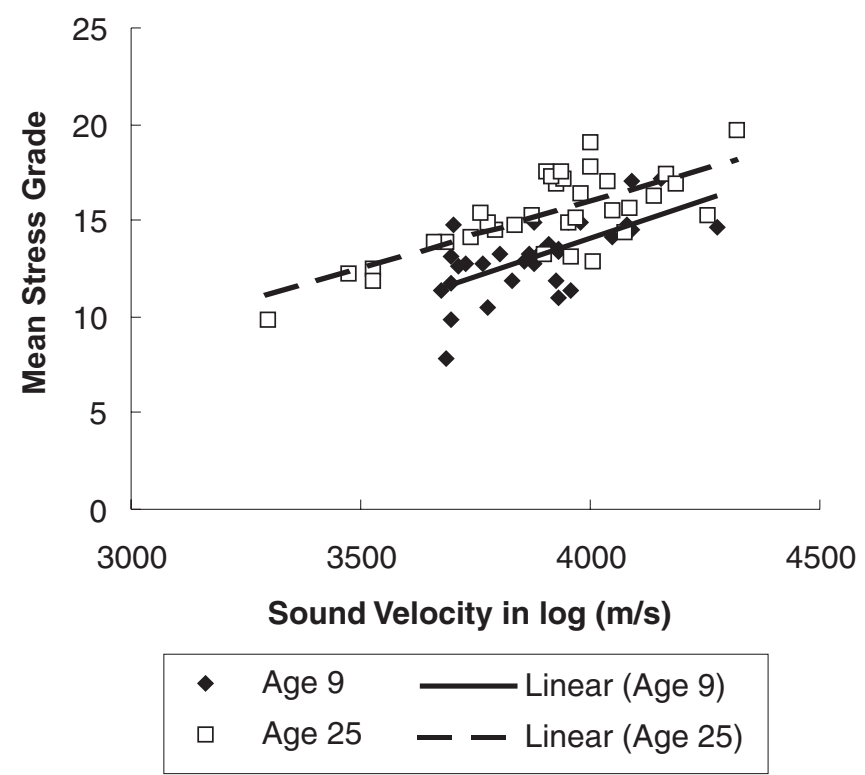

Figure 2. Relationship between mean stress grade of dried boards and velocity of sound within the green log for two age classes in E. dunnii (from [3]). 


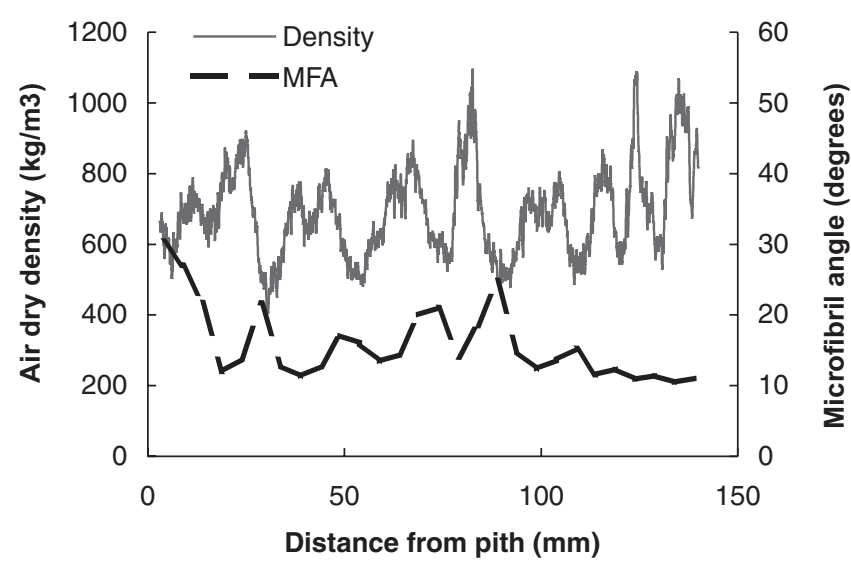

Figure 3. Pith to bark profile for air-dry density and micro fibril angle from SilviScan-2 for a ten-year-old E. globulus tree (Raymond, unpublished data).

assessment method used. Table $V$ presents a summary of patterns of change with time for each wood property together with, where possible, a suggested minimum age for assessment. For many wood properties there is little information available about patterns of change with increasing age, so it is not possible to suggest ages for assessment.

\section{GENETIC VARIATION}

For many wood quality traits there is little or no information available about the degree of genetic variation or the heritability of the trait. Most data is available for the easier to measure traits, such as basic density. The limited data available indicates that the wood properties generally exhibit

Table V. Change in each desired property with age and minimum age for potential assessment (adapted from [15]).

\begin{tabular}{lcc}
\hline & Change with age & Minimum age \\
\hline Basic density & Increase & 3 \\
Density variation & Constant & 5 \\
Microfibril angle & Decrease & 5 \\
Pulp yield and cellulose content & Increase & 5 \\
Lignin content & Decrease & 5 \\
Extractives & Increase & 8 \\
Fibre length & Increase & 5 \\
Growth Stresses & $?$ & $?$ \\
Modulus of elasticity & Increase & $?$ \\
Transverse Shrinkage & Increase & $?$ \\
Longitudinal shrinkage & Decrease & $?$ \\
Tension Wood & $?$ & $?$ \\
Incidence and extent of decay & $?$ & $?$ \\
Knot size (branch size) & Increase & $?$ \\
\hline
\end{tabular}

(? means unknown). different patterns of genetic variation and much higher heritabilities (after provenance effects are removed) than those found for other traits (figure 4). For example, a recent large genotype by environment interaction study in E. globulus $[11,21]$ found very different patterns of genetic variation for diameter, wood density, and pulp yield, predicted using near infrared reflectance analysis. For diameter there was relatively little difference amongst the provenances and a low heritability ( $\mathrm{h}^{2}$ of 0.16 to 0.33 ). For pulp yield, the provenance differences were small but the heritabilities moderate ( $h^{2}$ of 0.33 to 0.58$)$. In contrast, wood density had very large provenance differences together with high heritability $\left(h^{2}\right.$ of 0.67 to 1$)$. Genotype by environment interactions were evident for all traits but without practical importance for operational breeding programs.

Heritability estimates will vary according to the genetic material included in each trial and with different trial designs and sites. Therefore, the distribution of heritability estimates is also of interest. The distribution of published heritability estimates for basic density (figure 5) indicates that, whilst there is a spread in the estimates for both species, most of the estimates would be considered to be in the moderate to high range and that the heritabilities for E. globulus are, on average, somewhat higher than those for E. nitens.

One important issue when designing a breeding strategy is the relationship between tree growth rate and wood quality. Many breeding programs have based their selection, in early generations, predominantly on growth and survival, without considering wood quality. For most wood properties there is little or no information about the relationship with tree growth. Most data is available for tree diameter and basic density, where published estimates for genetic correlations
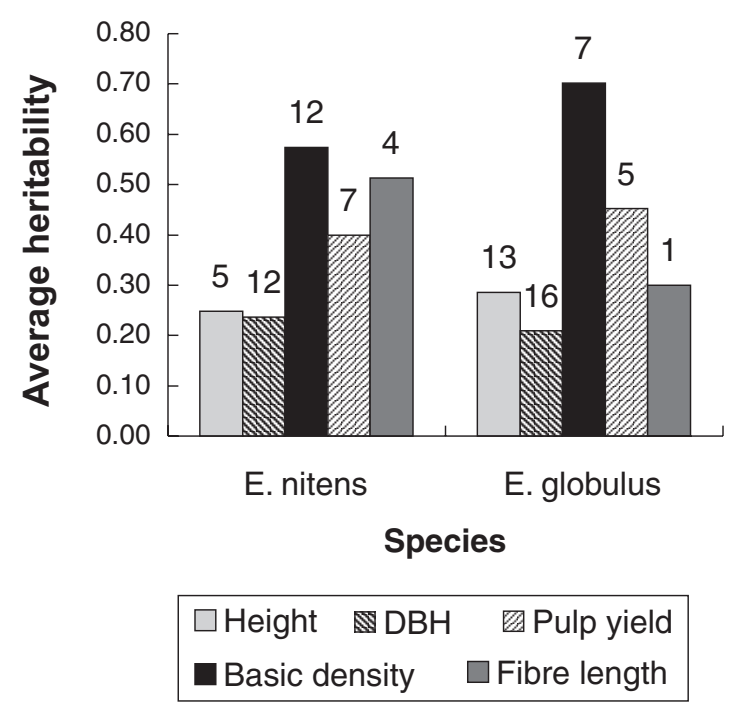

Figure 4. Summary of published within provenance heritability estimates for a range of traits in E. nitens and E. globulus. Bars represent mean of published estimates and the number of estimates included is given above each bar. 


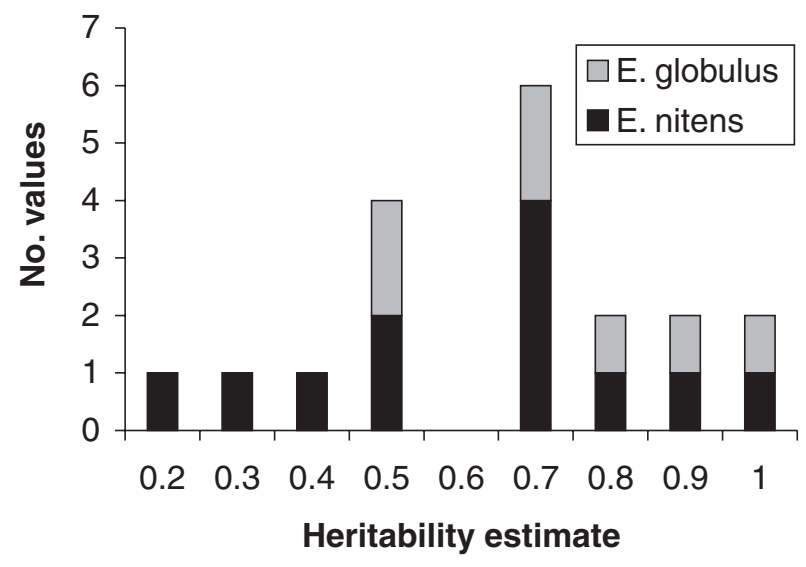

Figure 5. Distribution of published within provenance heritability estimates for basic density in E. nitens and E. globulus.

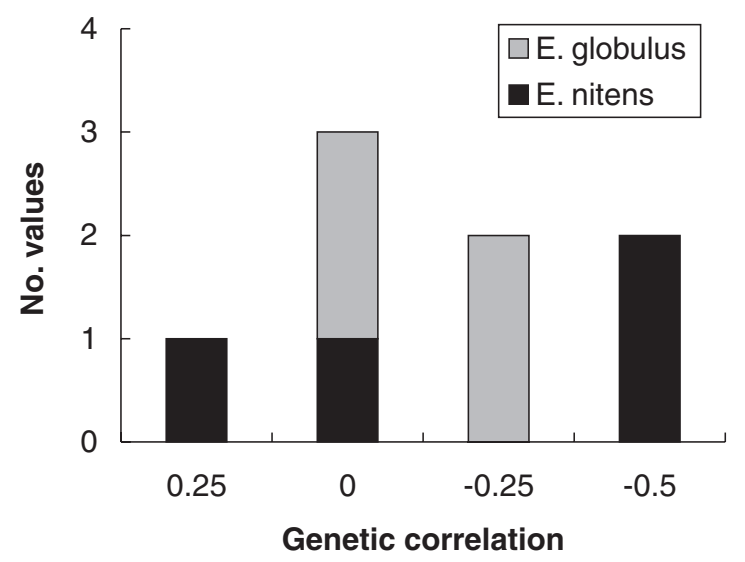

Figure 6. Distribution of published genetic correlations between basic density and tree diameter at breast height.

(figure 6) are variable but often close to zero, and there is no conclusive evidence for a strong negative relationship. These two traits appear to be largely independent and thus may be improved simultaneously.

\section{GENETIC MAPPING AND BIOTECHNOLOGY}

One rapidly expanding area of research is that relating to genetic mapping with the aim of locating quantitative trait loci (QTL) and genetic markers. Many different types of markers have been used and maps developed for a range of species [6, 10, 24]. Candidate genes have been identified [2, 5] and mapped and their location, relative to QTL sites identified. The degree of natural variation in both QTL and candidate genes is currently under investigation, together with studies on the biochemical pathways involved in wood formation.

\section{ISSUES AND CHALLENGES}

Several areas that offer significant challenges for the future development of breeding strategies for the improvement of wood properties in eucalypts are discussed below:

\subsection{Breeding objectives for products other than pulp}

Development of breeding objectives relies on determining the relationships between end product properties and tree and wood properties. Such information is currently limited but is essential to allow identification of key traits and for developing economic weights.

\subsection{Determining compatibility of alternative breeding objectives, markets and products}

At present there is a degree of uncertainty about the proposed market for many eucalypt plantations and, almost certainly, markets will change and new markets will emerge. One important question is whether breeding for the ideal wood properties for one product or market will produce a log that is suitable for a competing market. Are the desired wood properties compatible for the different alternative markets? A related question is whether to breed for a specific market or to produce a "general-purpose" tree that may be suitable for a range of markets?

\subsection{Reliable genetic parameter estimates for traits that are expensive or difficult to measure}

Development of a breeding strategy relies on good estimates of genetic parameters. For the more expensive or difficult to measure traits, obtaining parameter estimates based on a sufficiently large sample size is extremely expensive. One alternative may be to determine the phenotypic correlations between the indicator and desired traits and then obtain parameter estimates for indicator traits.

\subsection{Inclusion of multiple products and traits in a breeding program}

For any product class, there is more than one wood property considered to be important. If it is desired to breed for multiple products, the problem is magnified, particularly if there are adverse genetic correlations between the traits.

\subsection{Allocation of assessment resources}

The issue of how to best use limited resources for assessing the wood properties on large numbers of trees is an important issue. Alternatives include prioritising the traits for assessment, subsampling or only testing those trees considered to be elite based on other desired traits, such as tree growth rate. However, if only the elite trees are tested, the 
genetic parameter estimates obtained may be biased and not reflect the true values for the whole population.

\subsection{Incorporation of quantitative trait loci and marker aided selection}

One important question to be resolved is how to incorporate these technologies into a breeding program in a cost-effective manner.

\section{REFERENCES}

[1] Baillères H., Précontraintes de croissance et propriétés mécano-physiques de clones d'Eucalyptus (Pointe Noire-Congo): hétérogénéités, corrélations et interprétations histologiques, Ph.D. Thesis, Université de Bordeaux 1, 1994.

[2] Bossinger G., Leitch M.A., Isolation of cambium specific genes from Eucalyptus globulus Labill., in: Savidge R., Barnett J., Napier R. (Eds.), Cell and Molecular Biology of Wood Formation, BIOS Scientific, Oxford, 2000, pp. 203-207.

[3] Dickson R.L., Raymond C.A., Joe B., Wilkinson A.C., Segregation of Eucalyptus dunnii logs using acoustics, Workshop paper for University of Canterbury Wood Quality Research Group Annual Meeting, Unpublished proceedings, 2000, 9 p.

[4] Downes G.M., Hudson I.L., Raymond C.A., Dean G.H., Michell A.J., Schimleck L.R., Evans R., Muneri A., Sampling plantation eucalypts for wood and fibre properties, CSIRO Publishing, Melbourne, 1997.

[5] Gion J.-M., Rech P., Grima-Pettenati J., Verhaegen D., Plomion C., Mapping candidate genes in Eucalyptus with emphasis on lignification genes, Molecular Breeding 6 (2000) 441-449.

[6] Grattapaglia D., Bertolucci F.L.G., Penchel R., Sederoff R., Genetic mapping of quantitative trait loci controlling growth and wood quality traits in Eucalyptus grandis using a maternal half-sib family and RAPD markers, Genetics 144 (1996) 1205-1214.

[7] Greaves B.L., Borralho N.M.G., Raymond C.A., Breeding objective for plantation eucalypts grown for production of kraft pulp, For. Sci. 43 (1997) $465-472$.

[8] Kube P.D., Raymond C.A., Prediction of whole tree basic density and pulp yield using wood core samples in Eucalyptus nitens, Appita J. 55 (2002) 43-48.

[9] Michell A.J., Pulpwood quality estimation by near-infrared spectroscopic measurements on eucalypt woods, Appita J. 48 (1995) 425-428.

[10] Moran G.F., Thamarus K.A., Raymond C.A., Qiu D., Uren T., Southerton S.G., Genomics of eucalypt wood traits, Ann. For. Sci. 59 (2002) 645-650.

[11] Muneri A., Raymond C.A., Genetic parameters and genotype-by-environment interactions for basic density, pilodyn penetration and diameter in Eucalyptus globulus, For. Genet. 7 (2000) 321-332.
[12] Muneri A., Raymond C.A., Non-destructive sampling of Eucalyptus globulus and E. nitens for wood properties, Wood Sci. Technol. 35 (2001) $41-56$.

[13] Nicholson J.E., A rapid method for estimating longitudinal growth stresses in logs, Wood Sci. Technol. 5 (1971) 40-48.

[14] Ona T., Sonoda T., Ito K., Shibata M., Kato T., Ootake Y, Non-destructive determination of wood constituents by fourier transform Raman spectroscopy, J. Wood Chem. Technol. 17 (1997) 399-417.

[15] Raymond C.A, Tree breeding issues for solid wood production, IUFRO Conference on "The future of eucalypts for solid wood products", Launceston, Australia, March 2000, pp. 265-270.

[16] Raymond C.A., Balodis V., Dean G.H., Hot water extractives and pulp yield in provenances of Eucalyptus regnans, Appita 47 (1994) 159-162.

[17] Raymond C.A., Greaves B.L., Developing breeding objectives for kraft and cold soda soak (CCS) pulping of eucalypts, CTIA/IUFRO International Wood Quality Workshop on "Timber management toward wood quality and end-product value", Quebec City, Canada, August 18-22, 1997.

[18] Raymond C.A., Muneri A., Non-destructive sampling of Eucalyptus globulus and E. nitens for wood properties, Wood Sci. Technol. 35 (2001) 27-39.

[19] Raymond C.A., Schimleck L.R., Genetic parameters for cellulose content predicted using near infrared reflectance analysis in Eucalyptus globulus, Can. J. Forest Res. 32 (2001) 170-176.

[20] Raymond C.A., Schimleck L.R., Muneri A., Michell A.J., Non-destructive sampling of Eucalyptus globulus and E. nitens for wood properties, Wood Sci. Technol. 35 (2001a) 203-215.

[21] Raymond C.A., Schimleck L.R., Muneri A., Michell A.J., Genetic parameters and genotype-by-environment interactions for pulp yield predicted using near infrared reflectance analysis and pulp productivity in Eucalyptus globulus, Forest Genetics 8 (2001b) 213-224.

[22] Schimleck L.R., Michell A.J., Determination of within-tree variation of kraft pulp yield using near-infrared spectroscopy, Tappi J. 81 (1998) 229-236.

[23] Schimleck L.R., Michell A.J., Raymond C.A., Muneri A., Rapid assessment of pulpwood quality using near-infrared spectroscopy, in: 9th International Conference on Near-Infrared Spectroscopy, Verona, Italy, 14-18 June 1999.

[24] Sewell M.M., Neale D.B., Mapping quantitative traits in forest trees, in: Jain S.M., Minocha S.C. (Eds.), Molecular biology of woody plants, Vol. 1 Kluwer Academic Publishers, Netherlands, 2000, pp. 407-423.

[25] Wallis A.F.A., Wearne R.H., Wright P.J., Analytical characteristics of plantation eucalypt woods relating to kraft pulp yields, Appita J. 49 (1996) 427-432.

[26] Wallis A.F.A., Wearne R.H., Wright P.J., New approaches to rapid analysis of cellulose in wood, Proceedings of the International Symposium on Wood and Pulping Chemistry, Montreal, June 1997.

[27] Wright J.A., Birkett M.D., Gambino M.J.T., Prediction of pulp yield and cellulose content from wood samples using near infrared reflectance spectroscopy, Tappi J. 73 (1990) 164-166. 
